$\mathrm{W}$ ITH THE INTRODUCTION of improved management techniques and new, more effective materials, turfgrass culture has developed into a highly sophisticated technology. Among the new materials are the modern pesticides that control weeds, diseases, and insects. Proper irrigation, mowing, and fertilization practices remain the principal defenses against turfgrass pests; it is sometimes necessary, however, to complement the turfgrass cultural program with the intelligent selection and use of pesticides.

Pesticide formulations. Pesticides are chemicals that are active against one or more turfgrass pests. These chemicals are generally formulated as liquid concentrates - solutions (S) and emulsifiable concentrates (EG) wettable powders (WP), and granules (G). Liquid concentrates and wettable powders are usually added to water and applied to the turf with a sprayer. Granular materials can be applied with a fertilizer spreader.

Active ingredients. Pesticides must be accurately applied at correct rates to yield optimum results. Too little may control pests ineffectively; too much may injure the turf. The specific amount of material that should be applied depends upon the concentration of the pesticide (the "active ingredient") in the commercial preparation.

Concentration is usually expressed as a weight per unit volume or as a percent of the commercial preparation. For example, a 50 percent wettable powder is 50 percent active ingredients (a.i.) and 50 percent inert carrier. If the recommended rate of application is 12 pounds a.i. per acre, then 24 pounds of this commercial preparation are required to treat one acre. This is roughly equivalent to $1 / 2$ pound per 1,000 sq. ft. ( 43,560 sq. $\mathrm{ft} .=1$ acre).

Liquid formulations generally list the number of pounds of the active ingredient per gallon (lb. a.i./gal.) on the pesticide label. If the concentration is $4 \mathrm{lb}$./gal., then one quart of the product is required per acre to supply 1 pound of active ingredient per acre.

Precautions. Pesticides should be stored in their original containers with the label securely attached. Keep them in a cool, dry place that is inaccessible to children, pets, and irresponsible persons. Read the label before using the pesticide and follow all instructions carefully. A few minutes spent studying the information on a pesticide label may prevent misuse and needless accidents.

\section{WEED CONTROL}

Herbicides are pesticides that control one or more plant species. They may be classified into one of three types - contact, systemic, or soil sterilant - depending upon the nature of their activity on plants.

Contact herbicides kill plant parts covered by the chemical. Paraquat, a contact herbicide, is useful in
Table 1. - Chemical Control of Broadleaf Weeds in Turf

2,4-D $\mathrm{D}^{\mathrm{a}} \quad$ Silvex $^{\mathrm{b}}$ Mecoprop Dicamba $^{\mathrm{d}}$

\begin{tabular}{|c|c|c|c|}
\hline lack medic . . R & S-I & I & $\mathrm{S}$ \\
\hline $\begin{array}{l}\text { Carpetweed....... S } \\
\text { Chickweed, }\end{array}$ & I & I & $\mathrm{S}$ \\
\hline $\begin{array}{ll}\text { common......... } & \mathrm{R} \\
\text { mouse-ear....... } & \mathrm{R}\end{array}$ & $\begin{array}{l}S \\
S\end{array}$ & $\begin{array}{l}\text { S-I } \\
\text { S-I }\end{array}$ & $\begin{array}{l}S \\
S\end{array}$ \\
\hline 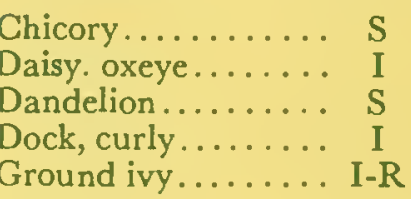 & $\begin{array}{c}\text { S } \\
I \\
\text { S } \\
I-R \\
\text { S-I }\end{array}$ & $\begin{array}{c}\text { S } \\
\text { I } \\
\text { S-I } \\
\text { I-R } \\
\text { I }\end{array}$ & $\begin{array}{c}\text { S } \\
I \\
\text { S } \\
\text { S } \\
\text { S-I }\end{array}$ \\
\hline 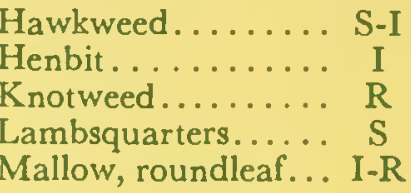 & $\begin{array}{c}\text { R } \\
\text { S } \\
\text { I } \\
\text { S } \\
\text { S-I }\end{array}$ & $\begin{array}{l}\mathrm{R} \\
\mathrm{I} \\
\mathrm{I} \\
\mathrm{S} \\
\mathrm{I}\end{array}$ & $\begin{array}{l}\text { S-I } \\
\text { S } \\
\text { S } \\
\text { S } \\
\text { S-I }\end{array}$ \\
\hline $\begin{array}{l}\text { Plantain, } \\
\text { broadleaf........ } \\
\text { buckhorn....... S } \\
\text { Purslane......... } \\
\text { Red sorrel....... I } \\
\text { R }\end{array}$ & $\begin{array}{c}\text { I } \\
\text { I } \\
\text { S-I } \\
\text { I }\end{array}$ & $\begin{array}{c}\text { I-R } \\
\text { I-R } \\
\text { R } \\
\text { R }\end{array}$ & $\begin{array}{l}R \\
R \\
S \\
S\end{array}$ \\
\hline 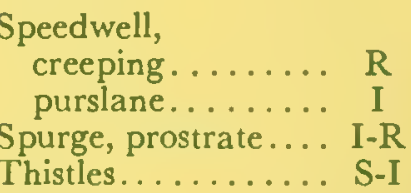 & $\begin{array}{c}\mathrm{R} \\
\mathrm{I} \\
\mathrm{I} \\
\mathrm{S}-\mathrm{I}\end{array}$ & $\begin{array}{l}\mathrm{R} \\
\mathrm{I} \\
\mathrm{I}\end{array}$ & $\begin{array}{c}\text { R } \\
\mathrm{I} \\
\mathrm{S}-\mathrm{I} \\
\mathrm{S}\end{array}$ \\
\hline $\begin{array}{ll}\text { Nhite clover........ } & \text { I } \\
\text { Nild carrot......... } & \text { S } \\
\text { Nild onion........ } & \text { I } \\
\text { Noodsorrel, yellow. } & \text { I } \\
\text { Yarrow.......... } & \text { I }\end{array}$ & $\begin{array}{l}\text { S } \\
\text { S-I } \\
R \\
\text { S-I } \\
I-R\end{array}$ & $\begin{array}{c}S \\
\text { S-I } \\
\text { R } \\
I \\
I-R\end{array}$ & $\begin{array}{c}\text { S } \\
\text { S } \\
\text { S-I } \\
I \\
\text { S }\end{array}$ \\
\hline
\end{tabular}

"A basic herbicide for use in combination with one or more of the others for broad-spectrum postemergence control of broadleaf weeds. Standard rate of application is $1 \mathrm{lb}$./A. Not recommended for use on bentgrass putting greens.

b Should not be used on bentgrass turf. Apply at $1 / 2$ to $3 / 4 \mathrm{lb}$./A. plus 2,4-D at the standard rate.

'Safe for use on bentgrass putting greens at $1 / 2$ to $1 \mathrm{lb} . / \mathrm{A}$. during cool weather periods. Can apply to general turf at 1 lb./A. with 2,4-D.

a very effective herbicide for broadleaf weed control when combined with $2,4-\mathrm{D}$ or as a 3 -way combination. Use at $1 / 4 \mathrm{lb}$./ A. with $2,4-D$; use at $1 / 8 \mathrm{lb}$. A . with $2,4-\mathrm{D}+$ silvex or with $2,4-\mathrm{D}$ t mecoprop. Do not apply above roots of trees and shrubs.

renovating turfs infested with extensive populations of annual weeds. Because paraquat has low soil residual activity, treated areas may be reseeded soon after chemical application.

Systemic herbicides, absorbed by plant organs and translocated throughout the plant, may be either selective, killing certain weeds without injuring desirable grasses, or nonselective, controlling. all vegetation. Mecoprop is a selective herbicide used to control broadleaf weeds in turf. Dalapon, a nonselective herbicide, is used to kill perennial weedy grasses such as quackgrass that cannot be controlled by selective herbicides.

Soil sterilants are chemicals that render the soil toxic to all plant life. How long the soil remains sterile depends

This circular was prepared by A. J. Turgeon, Assistant Professor, Department of Horticulture; M. C. Shurtleff, Professor, Department of Plant Pathology; and R. Randall, Assistant Professor, Agricultural Entomology. 
upon the material used, the rate of application, and the prevailing environmental conditions that affect decomposition of the herbicide in the soil. Soil sterilants have no place in turfgrass management; however, they are useful in preventing plant growth under fences and other areas that are difficult to mow.

Herbicides may be applied to prevent weeds from infesting a turf or to control weeds already present. Ben-

Table 2. - Chemical Control of Weed Grasses in Turf

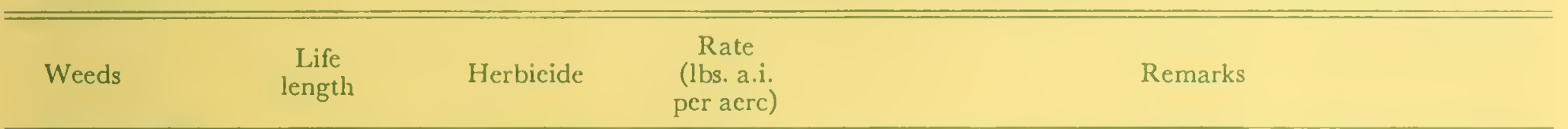

$\begin{array}{lll}\text { Annual bluegrass } & \begin{array}{l}\text { annual or } \\ \text { perennial }\end{array} & \begin{array}{l}\text { arsenatcs, lead } \\ \text { and calcium }\end{array}\end{array}$

Apply in late summer and again in early spring until selective toxicity is achieved. Then in late summer usc only half the recommended rate to maintain arsenatc toxicity. Omit phosphorus from fcrtilization program. Do not use on poorly drained sites. Apply at lower rates on bentgrass turf very carcfully, for too heavy an application can damage bentgrass.

benefin (Balan) $\quad 3$ Apply in early spring and late summer. Do not use on bent-

bensulide

(Bctasan)

DCPA (Dacthal)

12

endothall

(Endothal) grass putting greens.

Apply in late summer before the return of cool weather to prevent development of new plants. Fairly safe for use on bentgrass putting greens.

Apply in early spring and late summer. Do not use on bentgrass putting greens.

Apply during warm weather in late summer to Kentucky bluegrass turf. Repcat in two weeks if necessary. After last application, as annual bluegrass turns brown, overseed with dcsirable grasscs or inscrt plugs of sod into large bare areas to promote rapid healing. Has little or no preemergence activity.

\begin{tabular}{|c|c|c|}
\hline $\begin{array}{l}\text { Crabgrass } \\
\text { Foxtails }\end{array}$ & annual & benefin (Balan) \\
\hline Barnyardgrass & & $\begin{array}{l}\text { bensulide } \\
\text { (Betasan) }\end{array}$ \\
\hline & & DCPA (Dacthal) \\
\hline & & $\begin{array}{l}\text { siduron } \\
\text { (Tupersan) }\end{array}$ \\
\hline
\end{tabular}

Apply beforc emergence of crabgrass in carly spring. Not recommended for use on bentgrass turf.

Apply before emergenee of erabgrass in early spring.

Apply before emergence of erabgrass in carly spring. May injure bentgrasses and fine-leaf fescues.

Apply before emergence of crabgrass in early spring. Use at half the recommended rate in conjunction with seeding Kentucky bluegrass. May injure some bentgrasses and fineleaf fescues. Do not use on bermudagrass.

organic arseni- follow cals (DSMA, labels Apply soon after emergenec of crabgrass. Three applications at 7- to 10-day intervals are usually required. May cause some discoloration of the turf.

\begin{tabular}{|c|c|c|c|}
\hline Goosegrass & annual & $\begin{array}{l}\text { DCPA (Dacthal) } \\
\text { organic arseni- } \\
\text { cals (DSMA, } \\
\text { MSMA, etc.) }\end{array}$ & $\begin{array}{l}12 \\
\text { follow } \\
\text { labels }\end{array}$ \\
\hline $\begin{array}{l}\text { Tall fescue } \\
\text { Bentgrass } \\
\text { Nimblewill }\end{array}$ & perennial & $\begin{array}{l}\text { amitrole } \\
\text { dalapon } \\
\text { amitrole }+ \\
\text { dalapon } \\
\text { paraquat }\end{array}$ & $\begin{array}{c}4 \\
10 \\
2+5 \\
1\end{array}$ \\
\hline $\begin{array}{l}\text { Quackgrass } \\
\text { Bermudagrass }\end{array}$ & perennial & $\begin{array}{l}\text { amitrole }+ \\
\text { dalapon }\end{array}$ & $2+5$ \\
\hline
\end{tabular}

methyl bromide

436

Goosegrass is harder to control than crabgrass; complete control is rarely achieved.

Apply soon after emergence. Three or more applications at 7to 10-day intervals may be required for control. May cause some discoloration of the turf.

These give nonselective control. Amitrole and dalapon may persist in the soil for up to 4 and 6 weeks, respectively. Overseeding should be delayed until chemical residues have dissipated.

This gives nonselcctive control. Paraquat is highly toxic and should not be used by homeowners. It has no residual activity. Two successive applications may be required for control.

This gives nonselective control and may require more than one application. Effectiveness of control is enhanced by soil cultivation after foliage has turned brown. Wait at least 6 weeks before seeding.

Soil fumigant; must be applied under a sealed polyethylene tarp. Do not apply over roots of trees and shrubs. Professional use only.

\begin{tabular}{|c|c|c|c|}
\hline Nutsedge & perennial & $\begin{array}{l}\text { organic arseni- } \\
\text { cals (DSMA, } \\
\text { MSMA, etc.) } \\
\text { 2,4-D }\end{array}$ & $\begin{array}{c}\text { follow } \\
\text { labels } \\
1\end{array}$ \\
\hline
\end{tabular}

Treat soon after emergence before new nutlets form. Repeat application as soon as new growth is evident.

Apply when actively growing. Repeat application as often as necessary to control new growth. 
sulide is a preemergence herbicide that is applied in spring to prevent the development of crabgrass. Once the weed has germinated, however, DSMA may be used as a postemergence treatment to selectively control the crabgrass invader.

\section{INSECT CONTROL}

Insecticides are pesticides that reduce insect populations below levels that are injurious to turf. Although insecticide chemistry is quite varied, most of the commonly used materials act as contact poisons. Effective control is dependent upon ensuring contact between the insect and the insecticide. Therefore, control of soil-inhabiting insects (such as grubs) is best achicved by drenching the insecticicle into the soil, whereas foliar-feeding insects (for example, sod webworms) should be controlled by a foliar spray with no irrigation or rainfall for at least 24 hours.

Most insecticide applications are curative - the insect is controlled after the early signs of injury have been observed. One exception, however, is chlordane, a preventive insecticide: a single application should provide preventive grub control for five years or more.

No single insecticide will control all insect pests found in turf. Identify the specific insect before attempting control with an insecticide. Learn to recognize the early signs of injury from insects to avoid wide-scale loss of turf.

\section{DISEASE CONTROL}

Fungicides are pesticides that kill or inhibit the growth of clisease-causing fungi. Depending upon the manner in which they protect plants against infection, fungicides are of two general types: protective-contact fungicides and systemic fungicides.

Protective-contact fungicides are applied to seed, foliage, or soil to keep disease-causing fungi from entering plants. This kind of fungicide must be applied fairly frequently to turf (7- to 14-day intervals) since mowing and irrigation remove much of the surface chemical soon after application. Relatively high spray volumes ( 5 gal. water per $1,000 \mathrm{sq}$. ft.) are required to supply uniform and continuous coverage of the foliage by the fungicide. Adding spreader-stickers (surfactants) to the spray mixture facilitates good foliar coverage. Most of the available fungicides for turf are the protective-contact type.

Systemic fungicides, or chemotherapeutants, are absorbed and distributed within the plant, destroying established infections and controlling certain diseases for several weeks or months. These fungicides are absorbed principally by the roots and hence should be drenched or watered in for best results. Examples of systemic fungicides include benomyl (Tersan 1991), chloroneb (Tersan SP), TBZ (Tobaz, Mertect), and ethazol (Koban).

Table 3. - Chemical Control of Insects

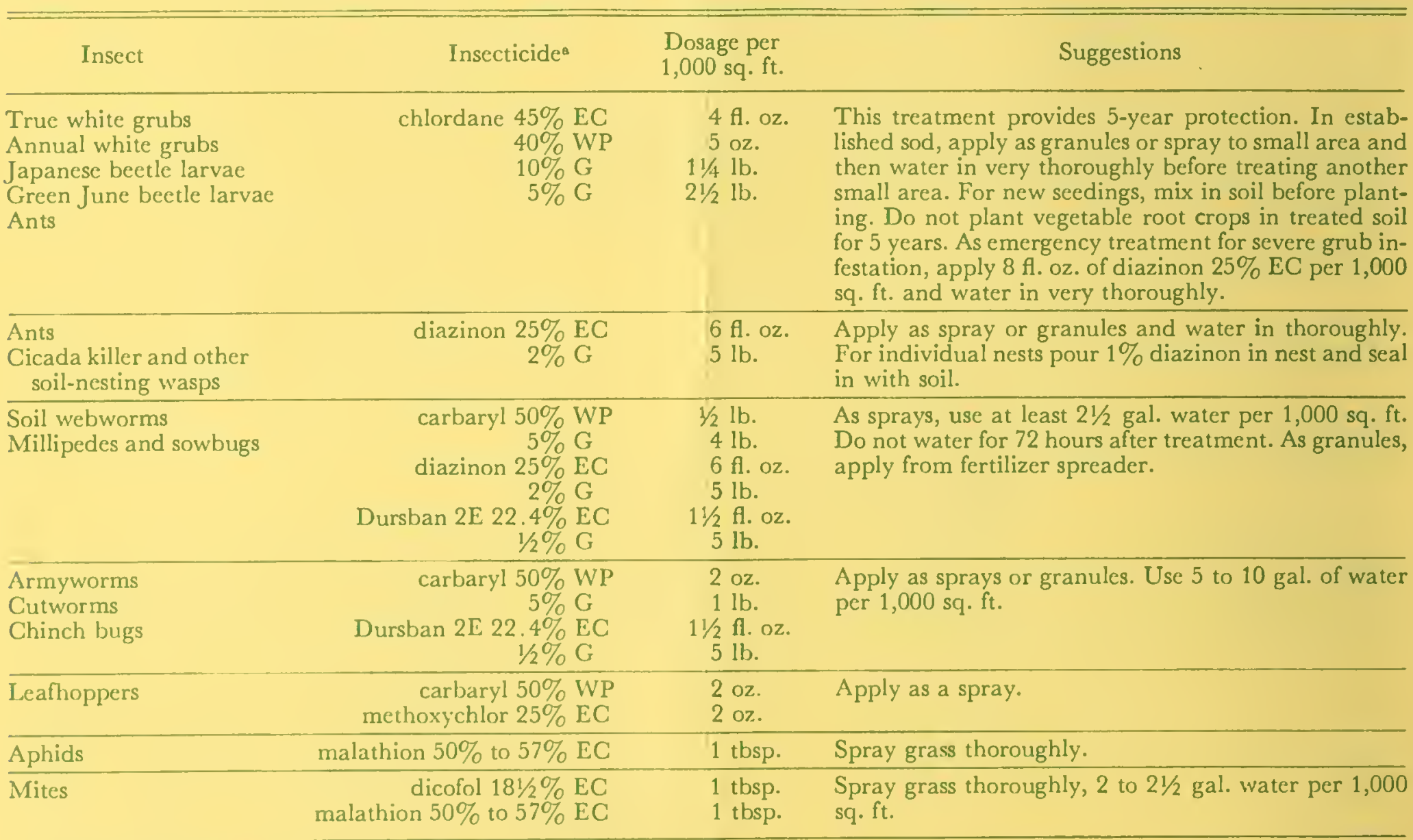

ase any of the insecticides recommended for a given group of insects, being sure to use the proper dosage for the formulation chosen. Follow labels. 
Table 4. - Chemical Control of Turfgrass Diseases

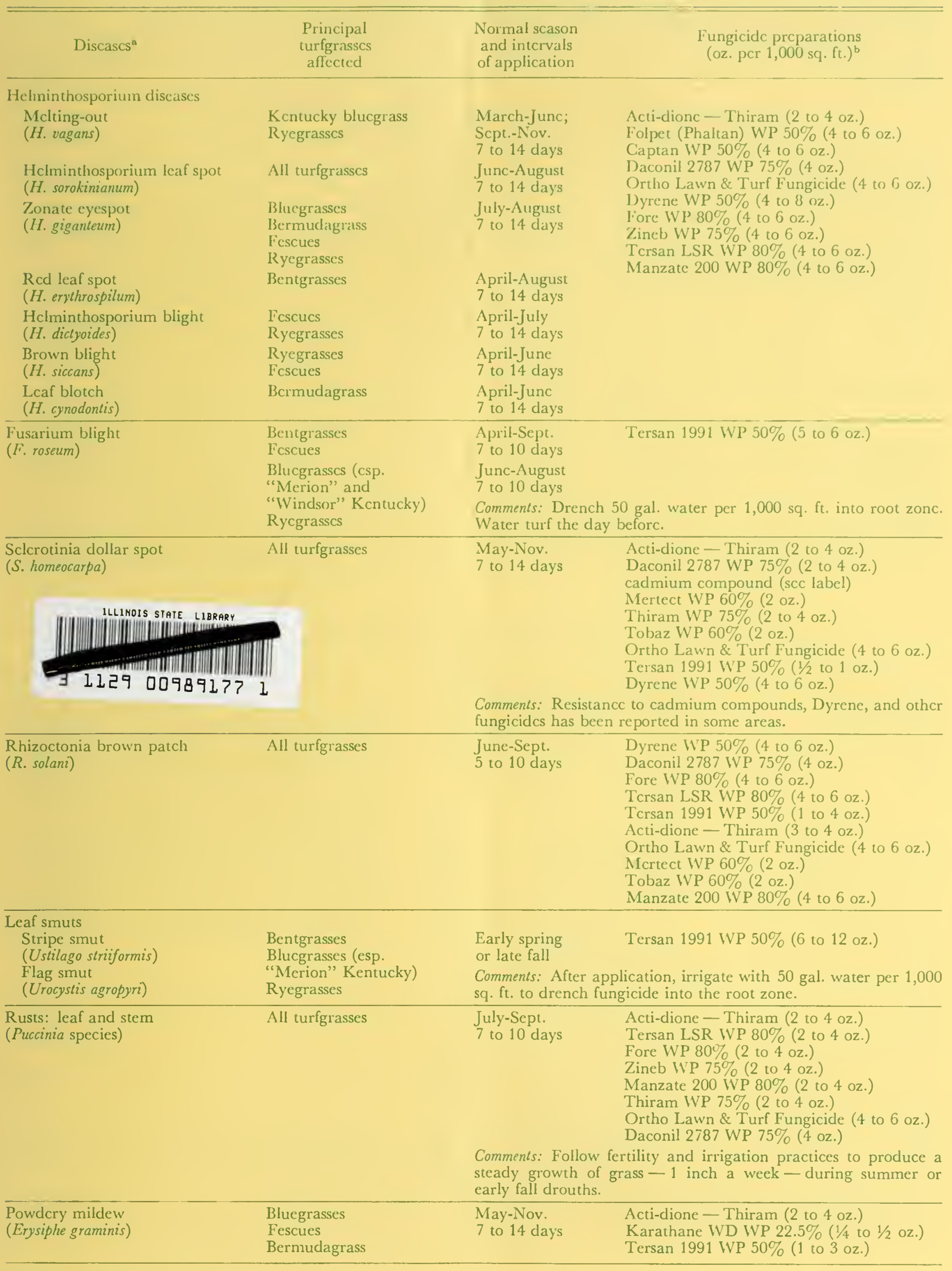


Table 4. - Chemical Control of Turfgrass Diseases (continued)

\begin{tabular}{|c|c|c|c|}
\hline Diseases $^{\mathrm{a}}$ & $\begin{array}{l}\text { Principal } \\
\text { turfgrasses } \\
\text { affected }\end{array}$ & $\begin{array}{l}\text { Normal season } \\
\text { and intervals } \\
\text { of application }\end{array}$ & $\begin{array}{l}\text { Fungicide preparations } \\
(\mathrm{oz} \text {. per } 1,000 \mathrm{sq} . \mathrm{ft} .)^{\mathrm{b}}\end{array}$ \\
\hline \multicolumn{4}{|l|}{ Snow molds } \\
\hline $\begin{array}{l}\text { Typhula blight }{ }^{\circ} \\
(T . \text { itoana, T. incarnata }) \\
\text { Fusarium patch } \\
(F . \text { nivale })\end{array}$ & All turfgrasses & $\begin{array}{l}\text { Late fall to } \\
\text { mid-spring }\end{array}$ & $\begin{array}{l}\text { Tersan SP WP } 65 \% \text { ( } 6 \text { to } 9 \mathrm{oz} .) \\
\text { Ortho Lawn \& Turf Fungicide (6 to } 12 \mathrm{oz.})\end{array}$ \\
\hline $\begin{array}{l}\text { Pythium blight, grease spot, } \\
\text { spot blight } \\
\text { (P. aphanidermatum, P. irregulare, } \\
P \text {. ultimum, P. torulosum, P. caten- } \\
\text { ulatum, P. dissotocum) }\end{array}$ & & \multicolumn{2}{|c|}{ Comments: Apply fungicide in 10 gal. water per 1,000 sq. ft. } \\
\hline
\end{tabular}

\begin{tabular}{l}
\hline Fairy rings \\
(Marasmius oreades, Lepiota
\end{tabular}

morgani, Agaricus campestris)

methyl bromide, chloropicrin,
hyde fumigation (see labels)

Comments: Soil temperature should be above $60^{\circ} \mathrm{F}$. for fumigation. Cover area with gas-proof cover for several days.

Instead of treating with fungicide, use root-feeder attachment on hose to drench rings with water.

\author{
Seed rot, damping-off, \\ seedling blights \\ (Pythium sp., Fusarium sp., \\ Rhizoctonia solani, Helmintho- \\ sporium sp., Colletotrichum \\ graminicolum)
}

All turfgrasses

fore planting.

fore planting. seedling emergence and 7 to 10 days later.
Captan or Thiram $50 \%$ to $75 \%$ (see label)

Folpet (Phaltan) WP 50\% (2 to $4 \mathrm{oz}$.)

Captan WP 50\% (2 to 4 oz.)

Dyrene WP $50 \%$ (2 to $4 \mathrm{oz}$.)

Kromad (4 to 6 oz.)

Daconil 2787 WP $75 \%$ (2 to $4 \mathrm{oz}$.)

Zineb WP $75 \%$ (2 to $4 \mathrm{oz}$.)

Thiram WP $75 \%$ (2 to 4 oz.)

Ortho Lawn \& Turf Fungicide ( 4 oz.)

Comments: Apply fungicide in 5 gal. water per 1,000 sq. ft.

Nematodes

(many genera and species)

All turfgrasses

All grasses except bentgrass: Mix 1.5 to 2 pints of Nemagon EC-2 or Fumazone $70 \mathrm{E}$ with 10 to $15 \mathrm{gal}$. of water and drench 1,000 sq. ft. of turf. Water turf immediately to ensure penetration of nematicide into soil and to prevent toxic effects. Treat in spring or fall (or both, if nematodes are a serious problcm) when soil temperature is above $60^{\circ} \mathrm{F}$. Aerifying turf before application improves rcsults. Do not apply chemical to newly seeded areas.

Bentgrass: Use only 1 pint of nematicide; otherwise, follow above instructions. Handle with extreme care, as nematicides are toxic to people and plants.

Slime molds
(Physarum cinereum, Fuligo sp.)

May-Sept.

Comments: Use any fungicide in this table when disease is first cvident.

Mow, rake, pole, or hose down to remove molds when seen.

Algae or green scum All turfgrasses

Apply when first Tersan LSR IVP $80 \%$ (2 to 4 oz.)

seen; reapply as Fore WP $80 \%$ (2 to 4 oz.) needed.

copper sulfate (1 to $2 \mathrm{oz}$.)

Apply when first ferrous ammonium sulfate (16 oz.) seen; reapply as needed.

\footnotetext{
a Causal fungus listed in parcntheses.

- Denotes either fungicide, coined name of that material, or representative trade names. Mention of a trade name or proprietary product does not constitute warranty of the product and does not imply approval of this material to the exclusion of comparable products that may be equally suitablc. Except where indicated, all materials should be applied in 3 to 5 gal. water per 1,000 sq. $\mathrm{ft}$. Use lower fungicide rates in preventive programs, higher rates for curative programs. Only one from each recommended group of preparations need be used.

"Other fungicides that control Typhula blight but not Fusarium patch include Thiram WP $75 \%$ (8 to 10 oz. per 1,000 sq. ft.) and cadmium compound (see label).

dFungicides that control Fusarium patch but not Typhula blight include Tersan 1991 WP $50 \%$ (3 to 8 oz. per 1,000 sq. ft.), Daconil 2787, Fore, Mertect, and Tobaz (sec labels).
}

Issued in furtherance of Caaperative Extensian Wark, Acts af May 8 and June 30, 1914, in caaperatian with the U.S. Department af Agriculture. JOHN B. CLAAR, Directar, Caoperative Extension Service, University af Illinais at Urbana-Champaign. 